\title{
Implementasi Metode Profile Matching Terhadap Sistem Pendukung Keputusan Penerimaan Dana Zakat pada Badan Amil Zakat Pertamina (BAZMA)
}

\author{
Evi Fadilah
}

\begin{abstract}
Pertamina Amil Zakat Agency (BAZMA) is a zakat management body currently actively receiving and distributing zakat to mustahik. The problem faced today is the determination of recipients of zakat funds must compare the results of the survey one by one so that those who are most entitled to receive zakat funds make subjective judgments. In order for BAZMA officers not to be wrong in distributing zakat funds, a decision support system is needed in determining the recipients of zakat funds where the assessment has been determined based on aspects, criteria and subcriteria. Because standards that become benchmarks have been determined, one of the suitable methods in making this decision support system is profile matching. Profile Matching method as an alternative alternative choice, with the accuracy of good results in the form of ranking and can reduce the occurrence of subjective judgments. The system created can facilitate the administrative part in processing mustahik data, help the chief coordinator in making decisions in a faster way, accuracy of good results and can reduce subjective judgments in determining the recipients of zakat funds.
\end{abstract}

Index Terms-Decision Support System, BAZMA, Profile Matching.

Abstrak--Badan Amil Zakat Pertamina (BAZMA) merupakan badan pengelola zakat saat ini secara aktif telah menerima dan menyalurkan zakat kepada mustahik. Masalah yang dihadapi saat ini adalah penentuan penerima dana zakat harus membandingkan hasil survey satu persatu sehingga didapat siapa yang paling berhak menerima dana zakat membuat penilaian subjektif. Agar petugas BAZMA tidak salah dalam penyaluran dana zakat maka dibutuhkan sistem pendukung keputusan dalam penentuan penerima dana zakat dimana pada sistem tersebut telah ditentukan penilaian berdasarkan aspek, kriteria-kriteria dan subkriteria. Karena standar yang menjadi tolak ukur telah ditentukan maka salah satu metode yang cocok dalam pembuatan sistem pendukung keputusan ini yaitu profile matching. Metode Profile Matching sebagai solusi alternative pilihan, dengan keakuratan hasil yang baik berupa perangkingan dan dapat mengurangi terjadinya penilaian secara subyektif. Sistem yang dibuat dapat mempermudah bagian

Evi Fadilah, Sistem Informasi, Universitas Islam Negeri Raden Fatah Palembang; email: evifadilah_uin@ radenfatah.ac.id administrasi dalam pengolahan data mustahik, membantu kepala koordinator dalam pengambilan keputusan dengan cara yang lebih cepat, keakuratan hasil yang baik dan dapat mengurangi penilaian secara subjektif dalam penentuan penerima dana zakat.

Kata Kunci- Sistem Pendukung Keputusan, BAZMA, Profile Matching.

\section{PENDAHULUAN}

Z akat merupakan salah satu kewajiban bagi umat Islam sebagai implementasi pelaksanaan Rukun Islam termasuk shadaqah dan infaq. Sesuai dengan pedoman Al-Quran dan As-Sunnah. Dalil yang menunjukkan kewajiban zakat adalah sebagai berikut :

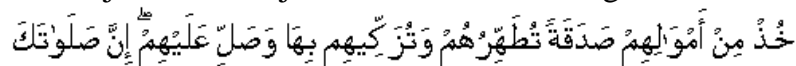

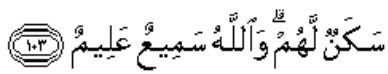

“Ambillah zakat dari sebagian harta mereka, dengan zakat itu kamu membersihkan dan mensucikan mereka dan mendo'alah untuk mereka. Sesungguhnya do'a kamu itu ketenteraman jiwa bagi mereka. Dan Allah Maha Mendengar lagi Maha Mengetahui." (Q.S. At-Taubah : 103).

Rasulullah SAW bersabda kepada sahabat Mu'adz tatkala beliau mengutusnya ke Yaman, "Beritahu mereka bahwa Allah SAW telah mewajibkan zakat kepada mereka di dalam harta yang diambil dari orang kaya mereka." (H.R. Muttafaqun Alaih).

Semakin tinggi kesadaran masyarakat untuk membayar zakat maka semakin banyak pula badan amil zakat berdiri di masyarakat, salah satunya yaitu badan amil zakat pertamina (BAZMA) Palembang. BAZMA merupakan badan pengelola zakat saat ini secara aktif telah menerima dan menyalurkan zakat kepada mustahik. Semakin banyak dana zakat yang masuk ke BAZMA maka semakin banyak pula dana yang akan disalurkan ke mustahik. Proses penentuan penerima zakat pada badan amil zakat pertamina Palembang masih dilakukan secara manual yaitu semua pekerjaan mulai dari awal, proses, hingga akhir pencatatan didokumentasikan dalam kertas secara tertulis. Masalah yang dihadapi saat ini adalah penentuan penerima dana 
zakat harus membandingkan hasil survey satu persatu sehingga didapat siapa yang paling berhak menerima dana zakat. Dengan cara ini dapat menimbulkan keakuratan hasil penerima zakat. Adapun penyebabnya yaitu belum ada sistem yang dapat membantu dalam memberikan keputusan penentuan penerima dana zakat dengan cara yang cepat dan

tepat sasaran. Agar petugas BAZMA tidak salah dalam penyaluran dana zakat maka dibutuhkan sistem pendukung keputusan dalam penentuan penerima dana zakat dimana pada sistem tersebut telah ditentukan penilaian berdasarkan aspek, kriteria-kriteria dan subkriteria. Karena standar yang menjadi tolak ukur telah ditentukan maka salah satu metode yang cocok dalam pembuatan sistem pendukung keputusan ini yaitu profile matching. Metode Profile Matching merupakan sebuah metode yang paling tepat digunakan dalam proses membandingkan antar kompetensi individu ke dalam kompetensi suatu jabatan sehingga dapat di ketahui perbedaan kompetensinya. Profile Matching sangat sesuai digunakan untuk pengambilan keputusan yang berhubungan dengan nilai prestasi jabatan dan kompetensi karena perhitungan yang di lakukan dengan pembobotan dan perhitungan gap dengan demikian untuk calon kandidat yang memiliki gap lebih kecil maka nilai bobotnya akan semakin besar. Profile Matching mempertimbangkan konsistensi yang logis dalam penilaian yang digunakan untuk menentukan prioritas sehingga menghasilkan alternatif yang tidak banyak[1].

\section{LANDASAN TEORI}

\section{A. Sistem Pendukung Keputusan}

Sistem pendukung keputusan yang dikemukakan oleh MC Leod (1998) yang menyatakan bahwa sistem pendukung keputusan merupakan sistem penghasil informasi yang ditujukan pada suatu masalah yang harus dibuat oleh manajer, sistem pendukung keputusan merupakan suatu sistem informasi yang ditujukan untuk membantu manajemen dalam memecahkan masalah yang dihadapinya.[2]

\section{B. Zakat}

Menurut Fuadi (2016:6) Zakat menurut Mazhab Maliki adalah mengeluarkan sebagian yang khusus dari harta yang khusus pula yang telah mencapai nisab (batas ukuran wajib zakat) kepada orang-orang yang berhak menerima (mustahiknya). Dengan syarat, kepemilikan itu penuh dan mencapai haul (setahun), bukan barang tambang dan bukan barang pertanian [3]

\section{Mustahik}

Mustahik adalah orang-orang yang berhak menerima zakat. Ketentuan tentang siapa saja yang berhak menerima zakat yaitu Orang fakir, Orang miskin, Amil Zakat, Muallaf, Riqab, Gharimin, Sabilillah, uIbnu Sabil.[4]

\section{Metode Profile Matching}

Metode profile matching atau pencocokan profil adalah metode yang sering digunakan sebagai mekanisme dalam pengambilan keputusan dengan mengasumsikan bahwa terdapat tingkat variabel prediktor yang ideal yang harus dimiliki oleh pelamar, bukannya tingkat minimal yang harus dipenuhi atau dilewati.[1]

Tahapan dan perumusan perhitungan dengan metode profile matching.[5]

1. Pembobotan

Tabel 1 Bobot Nilai Gap

\begin{tabular}{|c|l|l|l|}
\hline No & $\begin{array}{c}\text { Selisih } \\
\text { GAP }\end{array}$ & $\begin{array}{c}\text { Bobot } \\
\text { Nilai }\end{array}$ & Keterangan \\
\hline 1 & 0 & 5 & Kompetensi sesuai dengan yang dibutuhkan \\
\hline 2 & 1 & 4.5 & Kompetensi individu kelebihan 1 tingkat/level \\
\hline 3 & -1 & 4 & Kompetensi individu kurang 1 tingkat/level \\
\hline 4 & 2 & 3.5 & Kompetensi individu kelebihan 2 tingkat/level \\
\hline 5 & -2 & 3 & Kompetensi individu kurang 2 tingkat/level \\
\hline 6 & 3 & 2.5 & Kompetensi individu kelebihan 3 tingkat/level \\
\hline 7 & -3 & 2 & Kompetensi individu kurang 3 tingkat/level \\
\hline 8 & 4 & 1.5 & Kompetensi individu kelebihan 4 tingkat/level \\
\hline 9 & -4 & 1 & Kompetensi individu kurang 4 tingkat/level \\
\hline
\end{tabular}

2. Pengelompokan Core dan Secondary factor

a.Core Factor (Faktor Utama)

Core Factor merupakan aspek (kompetensi) yang paling menonjol/ paling dibutuhkan oleh suatu jabatan yang diperkirakan dapat menghasilkan kinerja optimal. Untuk menghitung core factor digunakan rumus :

$$
\mathrm{NCI}=\frac{\sum N C}{\sum I C}
$$

b. Secondary factor

Secondary factor adalah item-item selain aspek yang ada pada core factor. Untuk menghitung secondary factor digunakan rumus :

$$
\mathrm{NSI}=\frac{\sum N S}{\sum I S}
$$

3. Perhitungan Nilai Total

Dari perhitungan core factor dan secondary factor dari tiap-tiap aspek, kemudian dihitung nilai total dari tiap-tiap aspek diperkirakan berpengaruh pada kinerja tiap-tiap profile. Untuk menghitung nilai total dari masing-masing aspek, digunakan rumus :

\section{Perankingan}

$$
\mathrm{N}=(\mathrm{X}) \% \mathrm{NCI}+(\mathrm{X}) \% \mathrm{NSI}
$$

Hasil akhir dari proses profile matching adalah ranking dari kandidat untuk mengisi jabatan/posisi tertentu. Penetuan mengacu ranking pada hasil perhitungan yang ditujukan pada rumus dibawah ini :

Ranking $=(\mathrm{X}) \% \mathrm{~N} 1+(\mathrm{X}) \% \mathrm{~N} 2+(\mathrm{X}) \% \mathrm{~N} 3$

\section{METODE PENELITIAN}

\section{Metode Pengumpulan Data}

Adapun teknik-teknik pengambilan data yang peneliti lakukan dalam penelitian adalah sebagai berikut:

a. Observasi

Observasi adalah mengamati gejala-gejala sosial dalam kategori yang tepat, mengamati berkali-kali dan mencatat segera dengan alat bantu seperti alat pencatat, formulir dan alat mekanik.[6]

b. Wawancara

Wawancara merupakan metode pengumpulan data dengan cara peneliti mengajukan pertanyaan secara 
lisan kepada seseorang.[7]

c. Kepustakaan

Studi Pustaka yaitu melakukan pencarian materimateri pendukung dalam menyelesaikan permasalahan yang ada melalui buku-buku, internet, dan media informasi lainnya yang berhubungan dengan masalah yang di bahas.[8]

\section{Jenis Penelitian}

Jenis penelitian yang digunakan penelitian terapan sering juga disebut applied research, merupakan penelitian yang menyangkut aplikasi teori untuk memecahkan permasalahan tertentu. Ada tiga macam contoh dari penelitian terapan, yaitu :[9]

a. Penelitian Evaluasi, yaitu penelitian yang diharapkan dapat memberikan masukan atau mendukung pengambilan keputusan tentang nilai relatif dari dua atau lebih alternatif tindakan.

b. Penelitian dan Pengembangan, yaitu penelitian yang bertujuan untuk mengembangkan produk sehingga produk tersebut mempunyai kualitas yang lebih tinggi.

c. Penelitian Tindakan, yaitu penelitian yang dilakukan untuk segera dipergunakan sebagai dasar tindakan pemecahan masalah yang ada.

\section{Metode Pengembangan Sistem}

Model Prototype seringkali pelanggan mendefinisikan sejumlah sasaran perangkat lunak secara umum,tetapi tidak bisa mengidentifikasi spesifikasi kebutuhan yang rinci untuk fungsi-fungsi dan fitur-fitur yang nantinya akan dimiliki perangkat lunak yang dikembangkan. Berikut adalah gambar dari model Prototype.[10]

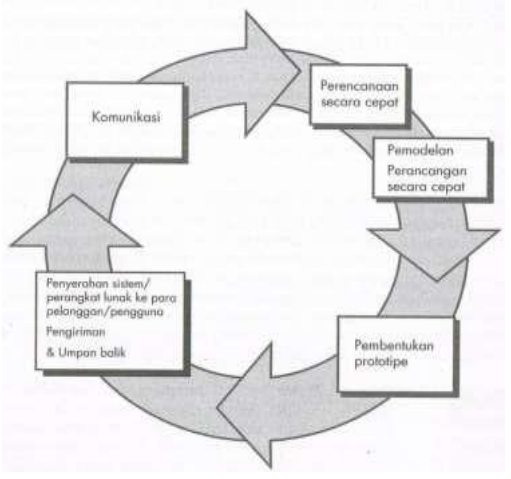

Gambar 1. Model Prototype

\section{HASIL PENELITIAN}

A. Simulasi Perhitungan Metode Profile Matching

1. Menentukan Aspek Penilaian dan Persentase

Tabel 2 Aspek Penilaian dan Persentase

\begin{tabular}{|l|l|l|}
\hline No & Aspek & Persentase (\%) \\
\hline 1 & Ekonomi & 60 \\
\hline 2 & Sosial & 40 \\
\hline
\end{tabular}

2. Menentukan Persentase Core Factor (CF) dan Secondary Factor (SF)

Tabel 3 Persentase Core Factor (CF) dan Secondary Factor (SF)

\begin{tabular}{|c|l|l|c|}
\hline No & Aspek & Tipe Factor & Persentase $(\%)$ \\
\hline 1 & Ekonomi & Core Factor & 65 \\
\hline
\end{tabular}

\begin{tabular}{|c|l|l|l|}
\hline & & Secondary Factor & 35 \\
\hline 2 & \multirow{2}{*}{ Sosial } & Core Factor & 70 \\
\cline { 3 - 4 } & & Secondary Factor & 30 \\
\hline
\end{tabular}

Menentukan Nilai Target dari setiap kriteria

Tabel 4 Nilai Target

\begin{tabular}{|r|l|l|c|c|}
\hline \multirow{2}{*}{ No } & Aspek & \multicolumn{1}{|c|}{ Kriteria } & $\begin{array}{c}\text { Nilai } \\
\text { Target }\end{array}$ & $\begin{array}{c}\text { Tipe } \\
\text { Factor }\end{array}$ \\
\hline \multirow{2}{*}{1} & Ekonomi & E1 : Pendapatan Keluarga & 5 & CF \\
\cline { 4 - 5 } & & $\begin{array}{l}\text { E2 :Penopang kebutuhan } \\
\text { Hidup }\end{array}$ & 3 & SF \\
\cline { 3 - 5 } & & E3 : Kondisi Rumah & 4 & SF \\
\cline { 3 - 5 } & & E4 : Jumlah Tanggungan & 4 & CF \\
\hline 2 & Sosial & S1: Status Pernikahan & 4 & CF \\
\cline { 3 - 5 } & & S2: Status Rumah & 3 & SF \\
\cline { 3 - 5 } & $\begin{array}{l}\text { S3:Pendidikan Terakhir } \\
\text { Tanggungan }\end{array}$ & 5 & CF \\
\cline { 3 - 5 } & & S4: Kendaraan Keluarga & 3 & SF \\
\hline
\end{tabular}

3. Menentukan Sub Kriteria

Tabel 5 Sub Kriteria

\begin{tabular}{|c|c|c|}
\hline Kriteria & Subkriteria & $\begin{array}{c}\text { Nilai } \\
\text { Sub Kriteria }\end{array}$ \\
\hline \multirow{5}{*}{$\begin{array}{l}\text { E1 } \\
\text { Pendapatan } \\
\text { Keluarga }\end{array}$} & 2 Juta Rupiah Atau Lebih & 1 \\
\hline & 1 juta - 1,9 Juta Rupiah & 2 \\
\hline & 500 Ribu - 1 Juta Rupiah & 3 \\
\hline & Kurang dari 500 ribu rupiah & 4 \\
\hline & Tidak Punya Pendapatan & 5 \\
\hline \multirow{3}{*}{$\begin{array}{l}\text { E2 } \\
\text { Penopang } \\
\text { Kebutuhan } \\
\text { Hidup }\end{array}$} & Ada Rutin & 1 \\
\hline & Ada Sekali-Sekali & 2 \\
\hline & Tidak Ada & 3 \\
\hline \multirow{4}{*}{$\begin{array}{l}\text { E3 : Kondisi } \\
\text { Rumah }\end{array}$} & Rumah Batu Permanen & 1 \\
\hline & Rumah Semi Permanen & 2 \\
\hline & Rumah Kayu & 3 \\
\hline & Rumah Gubuk & 4 \\
\hline \multirow{4}{*}{$\begin{array}{l}\text { E4 : Jumlah } \\
\text { Tanggungan }\end{array}$} & Tidak Ada Tanggungan & 1 \\
\hline & Antara 1-2 Orang & 2 \\
\hline & Antara 3-4 Orang & 3 \\
\hline & Lebih Dari 4 Orang & 4 \\
\hline \multirow{4}{*}{$\begin{array}{l}\text { S1 : Status } \\
\text { Pernikahan }\end{array}$} & Lajang & 1 \\
\hline & Nikah & 2 \\
\hline & Duda & 3 \\
\hline & Janda & 4 \\
\hline \multirow{3}{*}{$\begin{array}{l}\text { S2 : Status } \\
\text { Rumah }\end{array}$} & Milik Sendiri & 1 \\
\hline & Menumpang / Milik Saudara & 2 \\
\hline & Sewa / Kontrak & 3 \\
\hline \multirow{5}{*}{$\begin{array}{l}\text { S3 : } \\
\text { Pendidikan } \\
\text { Terakhir } \\
\text { Tanggungan }\end{array}$} & Tidak Ada Yang Sekolah & 1 \\
\hline & SD & 2 \\
\hline & SMP & 3 \\
\hline & SMA/ SMK & 4 \\
\hline & Perguruan Tinggi & 5 \\
\hline \multirow{3}{*}{$\begin{array}{l}\text { S4 } \\
\text { Kendaraan } \\
\text { Keluarga }\end{array}$} & Sepeda Motor & 1 \\
\hline & Sepeda & 2 \\
\hline & Tidak Punya Kendaraan & 3 \\
\hline
\end{tabular}

4. Tabel Penilaian Aspek Ekonomi

Tabel penilaian aspek ekonomi merupakan proses penilaian mustahik berdasarkan acuan penilaian pada Tabel 5 Sub kriteria. Setiap mustahik dilakukan penilaian berdasarkan hasil survey, jawaban yang telah dijawab oleh mustahik dilakukan penilaian sesuai dengan nilai sub kriteria yang telah ditentukan, dimana pada tabel sub kriteria terdapat masing-masing nilai sub kriteria, sehingga hasil penilaian dari aspek ekonomi dapat dilihat pada Tabel 6 .

Tabel 6 Penilaian Aspek Ekonomi

\begin{tabular}{|c|l|c|c|c|c|}
\hline No & Nama Mustahik & E1 & E2 & E3 & E4 \\
\hline 1 & Arifai & 3 & 2 & 2 & 3 \\
\hline 2 & Rugaya & 4 & 2 & 4 & 3 \\
\hline 3 & Syamudin & 5 & 3 & 3 & 2 \\
\hline
\end{tabular}




\begin{tabular}{|l|l|l|l|l|l|}
4 & Jaenal & 3 & 2 & 1 & 4 \\
\hline 5 & Shania & 1 & 3 & 2 & 2 \\
\hline 6 & Ali Usman & 1 & 1 & 1 & 2 \\
\hline 7 & Dariman Nur & 2 & 3 & 3 & 3 \\
\hline 8 & Cik Ayuma & 4 & 2 & 4 & 4 \\
\hline
\end{tabular}

5. Tabel Penilaian Aspek Sosial

Tabel penilaian aspek sosial merupakan proses penilaian mustahik berdasarkan acuan penilaian pada Tabel 5 Sub kriteria. Setiap mustahik dilakukan penilaian berdasarkan hasil survey, jawaban yang telah dijawab oleh mustahik dilakukan penilaian sesuai dengan nilai sub kriteria yang telah ditentukan, dimana pada tabel sub kriteria terdapat masing-masing nilai sub kriteria, sehingga hasil penilaian dari aspek sosial dapat dilihat pada Tabel 7.

Tabel 7 Penilaian Aspek Sosial

\begin{tabular}{|r|l|c|c|c|c|}
\hline \multicolumn{1}{|c|}{ No } & $\begin{array}{c}\text { Nama } \\
\text { Mustahik }\end{array}$ & S1 & S2 & S3 & S4 \\
\hline 1 & Arifai & 2 & 1 & 4 & 1 \\
\hline 2 & Rugaya & 4 & 2 & 2 & 2 \\
\hline 3 & Syamudin & 3 & 2 & 3 & 3 \\
\hline 4 & Jaenal & 2 & 3 & 5 & 2 \\
\hline 5 & Shania & 1 & 3 & 1 & 1 \\
\hline 6 & Ali Usman & 1 & 2 & 3 & 2 \\
\hline 7 & Dariman Nur & 2 & 1 & 3 & 2 \\
\hline 8 & Cik Ayuma & 4 & 1 & 4 & 3 \\
\hline
\end{tabular}

6. Perhitungan Pemetaan GAP untuk Aspek Ekonomi Tabel 8 Perhitungan Pemetaan GAP untuk Aspek Ekonomi

Tabel 8 Perhitungan Pemetaan GAP untuk Aspek Ekonomi
\begin{tabular}{|l|l|c|c|c|c|}
\hline No & $\begin{array}{c}\text { Nama } \\
\text { Mustahik }\end{array}$ & E1 & E2 & E3 & E4 \\
\hline 1 & Arifai & $(3-5)=-2$ & $(2-3)=-1$ & $(2-4)=-2$ & $(3-4)=-1$ \\
\hline 2 & Rugaya & $(4-5)=-1$ & $(2-3)=-1$ & $(4-4)=0$ & $(3-4)=-1$ \\
\hline 3 & Syamudin & $(5-5)=0$ & $(3-3)=0$ & $(3-4)=-1$ & $(2-4)=-2$ \\
\hline 4 & Jaenal & $(3-5)=-2$ & $(2-3)=-1$ & $(1-4)=-3$ & $(4-4)=0$ \\
\hline 5 & Shania & $(1-5)=-4$ & $(3-3)=0$ & $(2-4)=-2$ & $(2-4)=-2$ \\
\hline 6 & Ali Usman & $(1-5)=-4$ & $(1-3)=-2$ & $(1-4)=-3$ & $(2-4)=-2$ \\
\hline 7 & Dariman Nur & $(2-5)=-3$ & $(3-3)=0$ & $(3-4)=-1$ & $(3-4)=-1$ \\
\hline 8 & Cik Ayuma & $(4-5)=-1$ & $(2-3)=-1$ & $(4-4)=0$ & $(4-4)=0$ \\
\hline
\end{tabular}

7. Perhitungan Pemetaan GAP untuk Aspek Sosial

Tabel 9 Perhitungan Pemetaan GAP untuk Aspek Sosial

Tabel 9 Perhitungan Pemetaan GAP untuk Aspek Sosial
\begin{tabular}{|c|l|c|c|c|c|}
\hline No & $\begin{array}{c}\text { Nama } \\
\text { Mustahik }\end{array}$ & S1 & S2 & S3 & S4 \\
\hline 1 & Arifai & $(2-4)=-2$ & $(1-3)=-2$ & $(4-5)=-1$ & $(1-3)=-2$ \\
\hline 2 & Rugaya & $(4-4)=0$ & $(2-3)=-1$ & $(2-5)=-3$ & $(2-3)=-1$ \\
\hline 3 & Syamudin & $(3-4)=-1$ & $(2-3)=-1$ & $(3-5)=-2$ & $(3-3)=0$ \\
\hline 4 & Jaenal & $(2-4)=-2$ & $(3-3)=0$ & $(5-5)=0$ & $(2-3)=-1$ \\
\hline 5 & Shania & $(1-4)=-3$ & $(3-3)=0$ & $(1-5)=-4$ & $(1-3)=-2$ \\
\hline 6 & Ali Usman & $(1-4)=-3$ & $(2-3)=-1$ & $(3-5)=-2$ & $(2-3)=-1$ \\
\hline 7 & Dariman Nur & $(2-4)=-2$ & $(1-3)=-2$ & $(3-5)=-2$ & $(2-3)=-1$ \\
\hline 8 & Cik Ayuma & $(4-4)=0$ & $(1-3)=-2$ & $(4-5)=-1$ & $(3-3)=0$ \\
\hline
\end{tabular}

8. Pembobotan untuk Aspek Ekonomi

Tabel 10 Pembobotan untuk Aspek Ekonomi

\begin{tabular}{|c|l|c|c|c|c|}
\hline No & Nama Mustahik & $\mathbf{E} 1[\mathbf{c}]$ & $\mathbf{E 2}[\mathbf{s}]$ & $\mathbf{E 3}[\mathbf{s}]$ & $\mathbf{E 4}[\mathbf{c}]$ \\
\hline 1 & Arifai & 3 & 4 & 3 & 4 \\
\hline 2 & Rugaya & 4 & 4 & 5 & 4 \\
\hline 3 & Syamudin & 5 & 5 & 4 & 3 \\
\hline 4 & Jaenal & 3 & 4 & 2 & 5 \\
\hline 5 & Shania & 1 & 5 & 3 & 3 \\
\hline 6 & Ali Usman & 1 & 3 & 2 & 3 \\
\hline 7 & Dariman Nur & 2 & 5 & 4 & 4 \\
\hline 8 & Cik Ayuma & 4 & 4 & 5 & 5 \\
\hline
\end{tabular}

9. Pembobotan untuk Aspek Sosial

Tabel 11 Pembobotan untuk Aspek Sosial

\begin{tabular}{|l|l|c|c|c|c|}
\hline No & Nama Mustahik & S1 [c] & S2 [s] & S3 [c] & S4 [s] \\
\hline 1 & Arifai & 3 & 3 & 4 & 3 \\
\hline 2 & Rugaya & 5 & 4 & 2 & 4 \\
\hline 3 & Syamudin & 4 & 4 & 3 & 5 \\
\hline 4 & Jaenal & 3 & 5 & 5 & 4 \\
\hline 5 & Shania & 2 & 5 & 1 & 3 \\
\hline 6 & Ali Usman & 2 & 4 & 3 & 4 \\
\hline 7 & Dariman Nur & 3 & 3 & 3 & 4 \\
\hline 8 & Cik Ayuma & 5 & 3 & 4 & 5 \\
\hline
\end{tabular}

10. Perhitungan Core Factor dan Secondary Factor dan ranking

Tabel 12 Perhitungan Core Factor dan Secondary Factor dan ranking

\begin{tabular}{|l|l|l|l|l|}
\hline \multirow{2}{*}{ No } & Nama Mustahik & $\mathbf{N}(\mathbf{E})$ & $\mathbf{N}(\mathbf{S})$ & Nilia Ranking \\
\hline 1 & Arifai & 3,5 & 3,35 & 3,44 \\
\hline 2 & Rugaya & 4,175 & 3,65 & 3,965 \\
\hline 3 & Syamudin & 4,175 & 3,8 & 4,025 \\
\hline 4 & Jaenal & 3,65 & 4,15 & 3,85 \\
\hline 5 & Shania & 2,7 & 2,25 & 2,52 \\
\hline 6 & Ali Usman & 2,175 & 2,25 & 2,485 \\
\hline 7 & Dariman Nur & 3,525 & 3,15 & 3,375 \\
\hline 8 & Cik Ayuma & 4,5 & 4,35 & 4,44 \\
\hline
\end{tabular}

\section{B. Flowchart Sistem berjalan}

Flowchart system yang berjalan secara aktif yaitu bagian administrasi mencari informasi terkait tentang calon mustahik lainnya kepada calon mustahik dan setelah menerima informasi bagian administrasi akan meminta tim survey untuk datang ketempat calon mustahik, tim survey akan memberikan formulir pengisian calon mustahik dan melakukan survey. Data hasil survey akan diberikan kepada bagian administrasi setelah itu akan diproses dan diarsipkan kedokumen calon mustahik, selanjutnya memberikan data calon mustahik kepada kepala koordinator jika menurut kepala koordinator layak untuk diberikan maka bagian administrasi akan mengkonfirmasi kepada mustahik penerima dana zakat Bazma. 


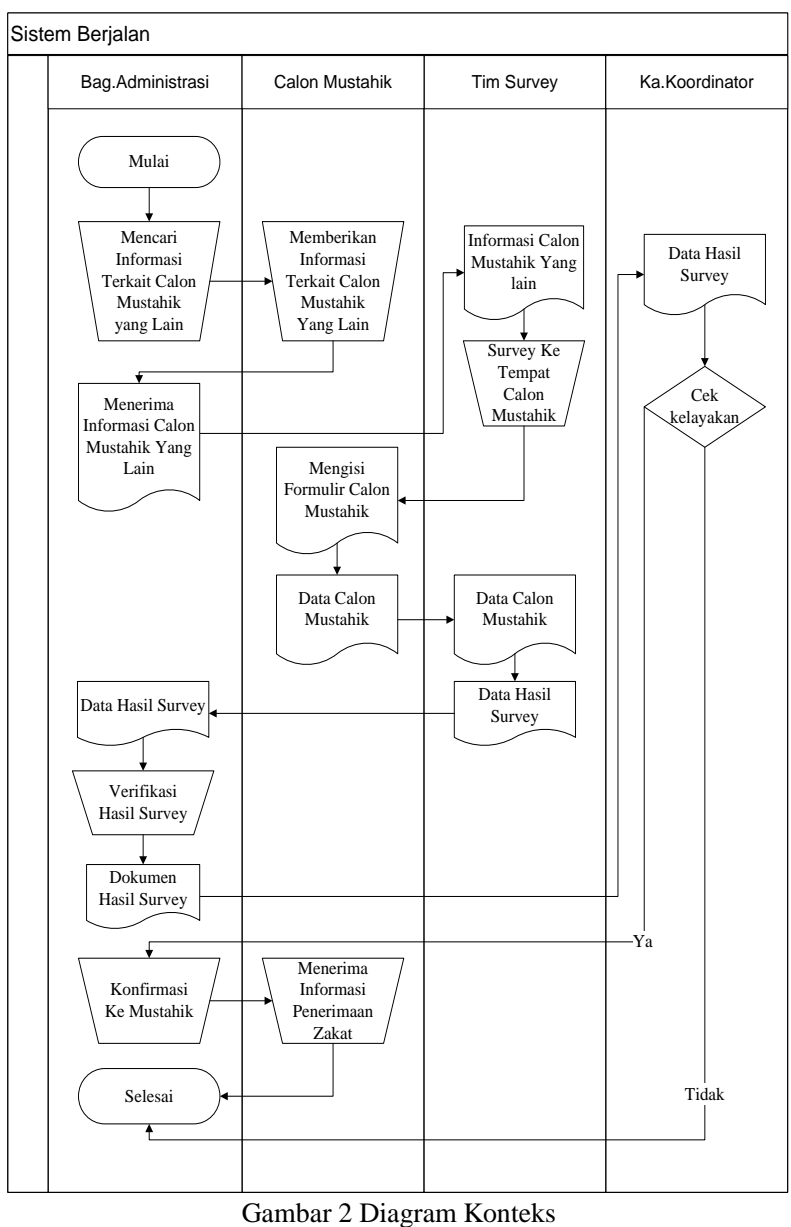

C. Pemodelan Proses

1. Diagram Konteks

Diagram konteks dari implementasi metode profile matching terhadap sistem pendukung keputusan penerimaan dana zakat pada badan amil zakat pertamina (BAZMA) terdiri dari entitas Bagian Administrasi dimana bagian administrasi dapat melakukan entri data mustahik, data tim survey, data aspek, data factor, data kriteria penilaian, data sub kriteria penilaian, data penilaian, dan data user. Informasi yang didapat berupa informasi nilai awal dan GAP, nilai NCF dan NSF, serta informasi nilai Ranking. Entitas Kepala koordinator mendapatkan laporan ranking mustahik, dapat dilihat pada Gambar 3.

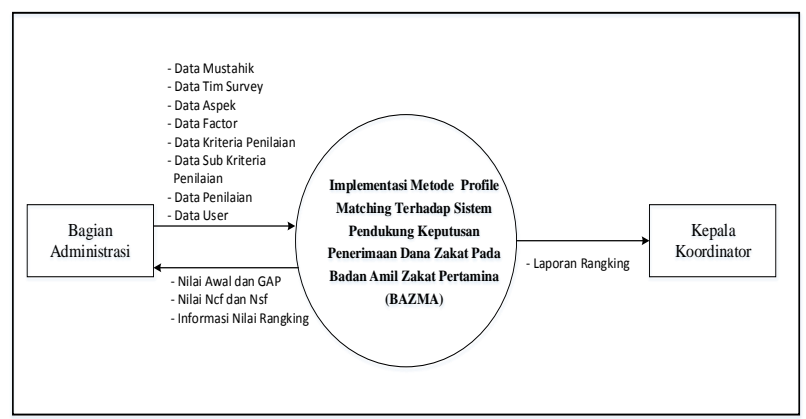

Gambar 3 Diagram Konteks

2. DFD Level Nol

Diagram Level Nol pada implementasi metode profile matching terhadap sistem pendukung keputusan penerimaan dana zakat pada badan amil zakat pertamina
(BAZMA) terdiri dari 10 proses yaitu dapat dilihat pada Gambar 4:

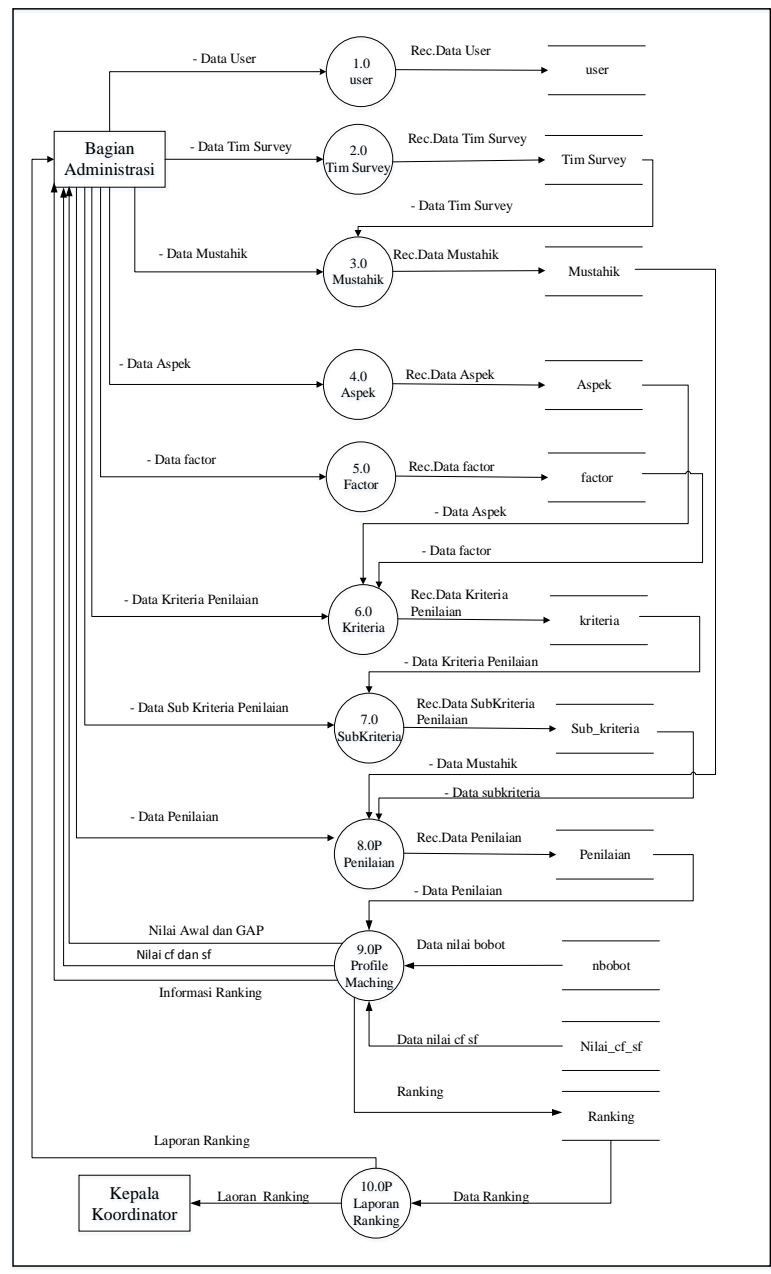

Gambar 4 DFD Level Nol

\section{Pemodelan Data}

Pemodelan data pada implementasi metode profile matching terhadap sistem pendukung keputusan penerimaan dana zakat pada badan amil zakat pertamina (BAZMA) menggunakan Entity Relational Diagram (ERD) terdiri dari 10 entitas dimana masing-masing entitas saling terelasi. ERD dapat dilihat pada Gambar 5.

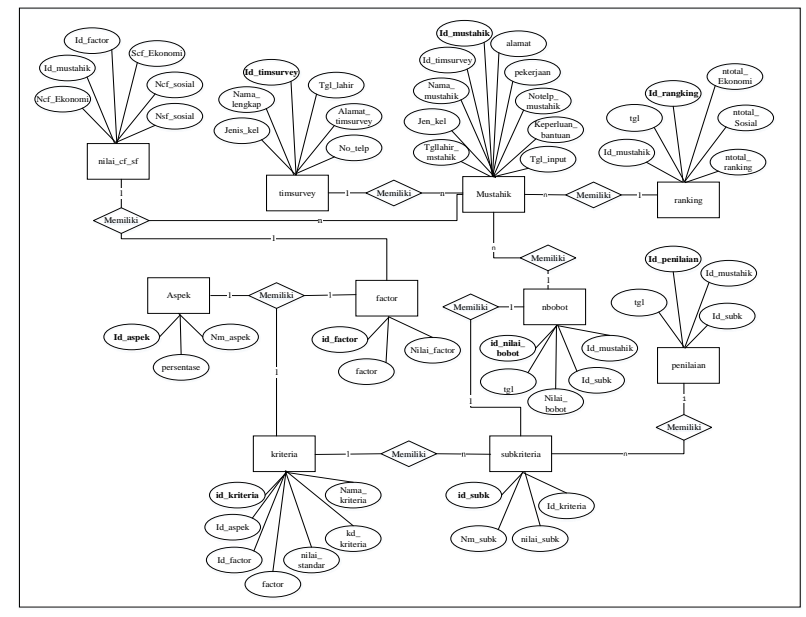

Gambar 5 Pemodela Data 


\section{E. Pembahasan}

Implementasi metode profile matching terhadap sistem pendukung keputusan penerimaan dana zakat pada badan amil zakat pertamina (BAZMA) bertujuan untuk membantu bagian kepala koordinator menentukan siapa yang berhak menerima dana zakat. Pada Implementasi metode profile matching ini terdapat 2 aktor yaitu bagian administrasi dan kepala koordinator. Setiap aktor memiliki hak akses untuk masuk kedalam sistem pendukung keputusan sesuai dengan user yang telah didaftarkan. Pertama bagian administrasi bertugas untuk memasukkan data user, data mustahik, data tim survey, aspek penilaian, factor, keriteria penilaian, subkriteria penilaian, melakukan penilaian terhadap mustahik, mendapatkan informasi nilai awal mustahik, mendapatkan informasi nilai factor dan ranking mustahik. Bagian administrasi juga memiliki hak untuk menambah, mengubah dan menghapus data mustahik, tim survey, aspek penilaian, factor, kriteria penilaian, subkriteria penilaian. Kedua kepala koordinator menerima laporan penerima dana zakat teranking.

\section{F. Implementasi}

\section{Bagian Administrasi}

Bagian administrasi akan membahas tentang halaman yang bisa diakses oleh bagian administrasi terhadap implementasi metode profile matching terhadap sistem pendukung keputusan penerimaan dana zakat pada badan amil zakat pertamina (BAZMA) terdiri dari form login, menu admin, form mustahik, form tim survey, form aspek penilaian, form factor, form kriteria penilaian, form sub kriteria penilaian, form penilaian mustahik, tampilan nilai awal mustahik, tampilan nilai factor dan ranking mustahik, tampilan laporan penerima zakat.

\section{a. Interface View Data Kriteria}

Pada view data kriteria, bagian administrasi bisa melakukan ubah data kriteria, hapus data kriteria serta. View data kriteria dapat dilihat pada Gambar 6.

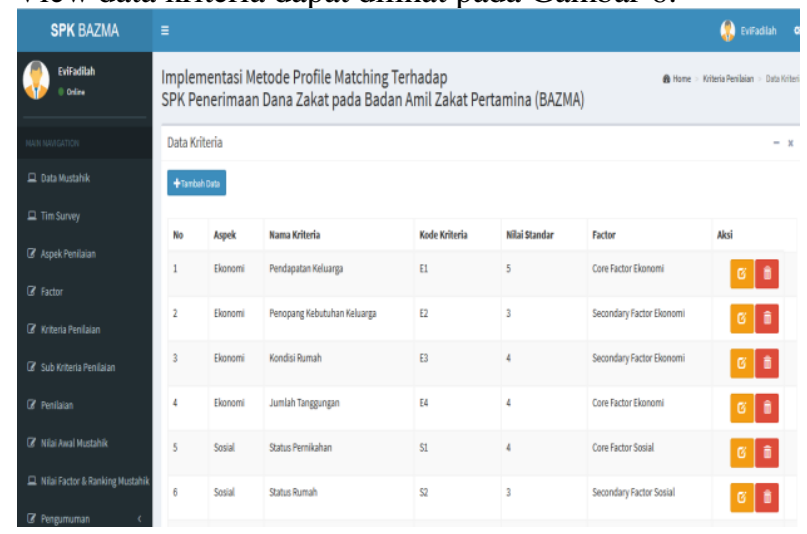

Gambar 6 Interface View Data Kriteria

b. Interface View Data Sub Kriteria

Pada view data sub kriteria, bagian administrasi bisa melakukan ubah data sub kriteria, hapus data sub kriteria serta dapat melakukan pencarian data sub kriteria dengan cara mengetikkan keyword kriteria, sub kriteria atau nilai persentase pada kolom search. View data sub kriteria dapat dilihat pada Gambar 7.

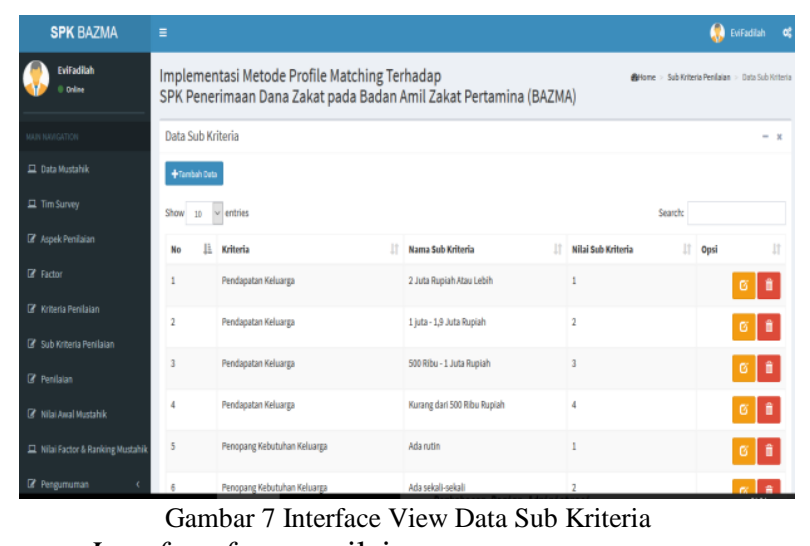

c. Interface form penilaian

Interface form penilaian mustahik merupakan halaman yang yang berfungsi untuk entri data penilaian mustahik. Nama mustahik yang telah terdaftar secara otomatis telah tampil pada list menu mustahik. Form penilaian mustahik terdiri dari data mustahik, pendapatan keluarga, penopang kebutuhan keluarga, kondisi rumah, jumlah tanggungan, status pernikahan, status rumah, pendidikan terakhir tanggungan, kendaraan keluarga. Pada form penilaian mustahik terdapat 3 tombol yaitu tombol back berfungsi kembali kehalaman utama bagian administrasi, tombol hitung berfungsi untuk melakukan proses perhitungan dengan metode profile matching, dan tombol reset berfungsi untuk membatalkan proses perhitungan sehingga data pada form penilaian menjadi kosong. Interface form penilaian dapat dilihat pada Gambar 8

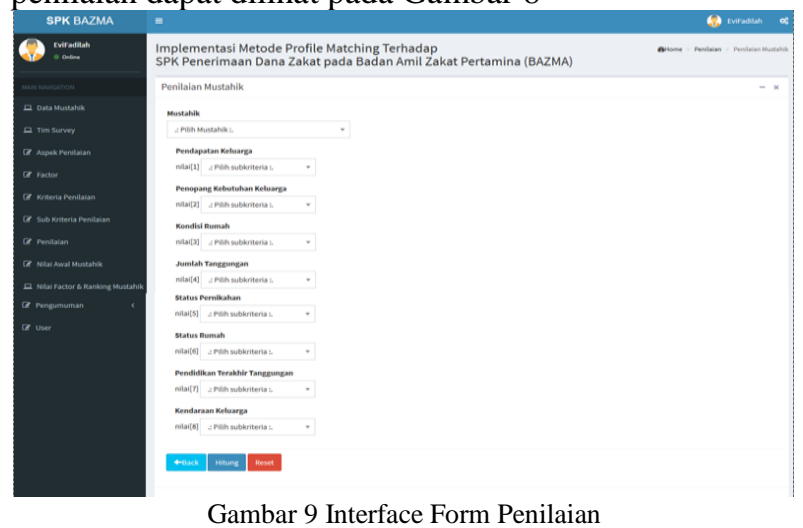

d. Interface view nilai awal

Interface view nilai awal merupakan halaman yang berfungsi untuk melihat data nilai awal dan selisih nilai mustahik. View nilai awal terdiri dari nama mustahik, nama kriteria, nilai awal (NA), Nilai Standar (NS), Selisih nilai (NA-NS). Desain view nilai awal dapat dilihat pada Gambar 10 .

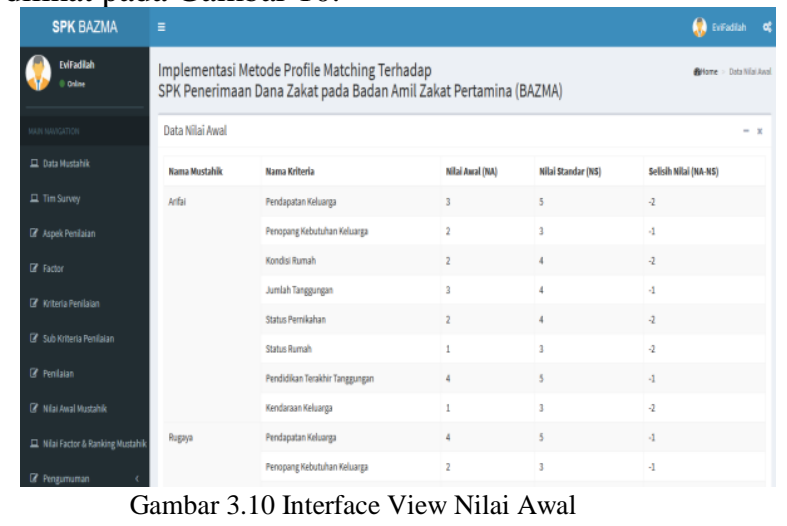


e. Interface view nilai factor

Interface view nilai factor merupakan halaman yang berfungsi untuk melihat nilai factor. View nilai factor terdiri dari data nama mustahik, Nilai Core Factor (NCF) Ekonomi, Nilai Secondary Factor (NSF) Ekonomi, Nilai Core Factor (NCF) Sosial, Nilai Secondary Factor (NSF) Sosial. Interface view nilai factor dapat dilihat pada Gambar 11.

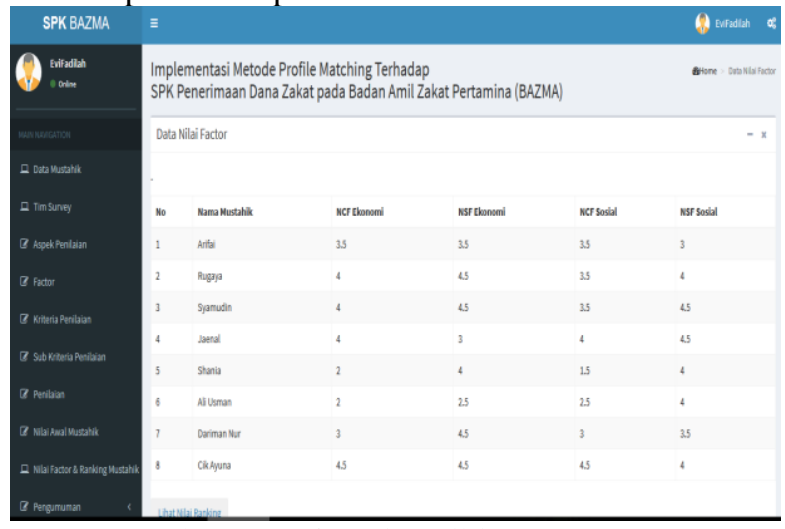

Gambar 11 Interface View Nilai Factor

f. Interface view nilai ranking

Interface view nilai ranking merupakan halaman yang berfungsi untuk melihat nilai ranking mustahik. Ranking mustahik terurut mulai dari rangking terkecil sampai ranking terbesar. Nilai Ranking mustahik didapat dari total penilaian aspek ekonomi dan aspek sosial sehingga mengasilkan nilai ranking, nilai rangking terbesar dinyatakan ranking tertinggi dan sebaliknya nilai ranking terendah dinyatakan sebagai ranking terendah. View nilai ranking terdiri dari data tanggal, nama mustahik, nilai total aspek ekonomi, nilai total aspek social, nilai ranking, dan ranking mustahik. Desain view nilai ranking dapat dilihat pada Gambar 12.

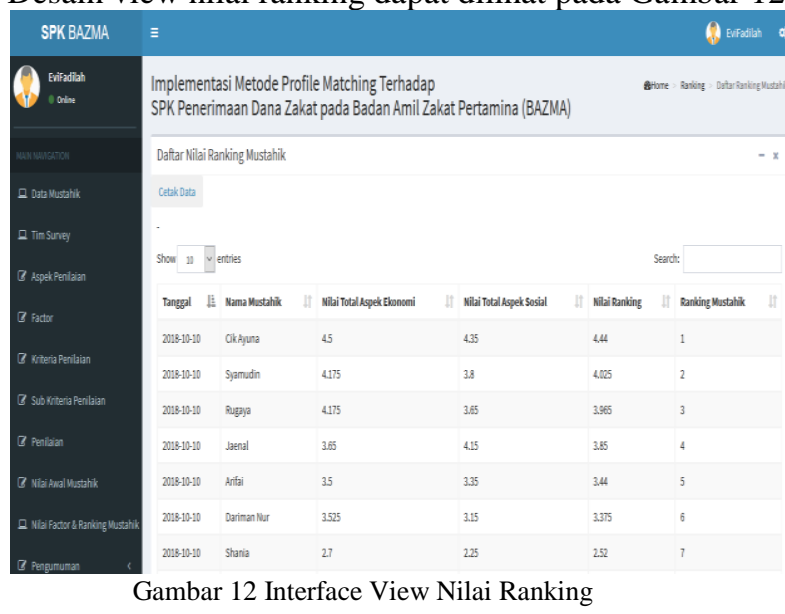

2. Kepala Koordinator

a.Interface Menu

Interface menu kepala koordinator terdiri dari menu data nilai, dan cetak laporan. Setelah bagian administrasi berhasil login maka langsung tampil data nilai pada halaman awal. Pada halaman data nilai terdapat kolom pencarian, kepala koordinator bisa melakukan pencarian data nilai ranking mustahik. Interface menu admin dapat dilihat pada Gambar 13.

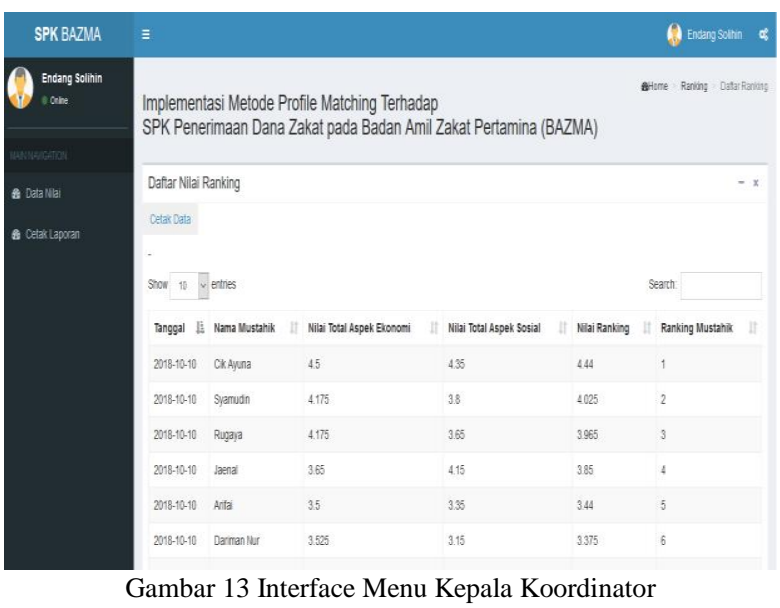

b. Interface Laporan

Pada halaman menu cetak laporan menampilkan informasi penerima dana zakat terurut mulai dari ranking terkecil hingga ranking terbesar. Interface laporan dapat dilihat pada Gambar 14.

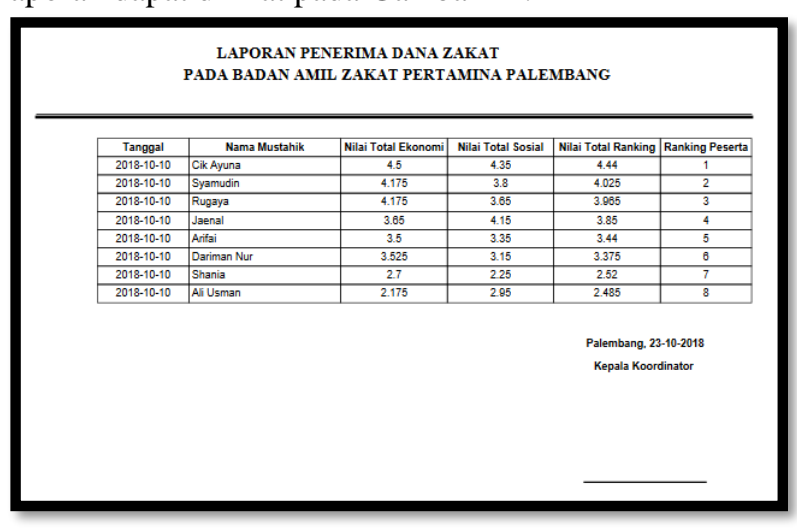

Gambar 14 Interface Laporan

\section{KESIMPULAN}

Berdasarkan penelitian yang telah dilakukan adapun cara mengimplementasikan metode Profile Matching terhadap sistem pendukung keputusan penerimaan dana zakat pada Badan Amil zakat Pertamina (BAZMA) menggunakan metode pengembangan sistem dengan prototype dikarenakan cocok untuk membangun sistem karena pengerjaannya yang relatif singkat. Bahasa pemrograman yang digunakan PHP dan basis data menggunakan MySQL, sehingga sistem yang dibuat dapat mempermudah bagian administrasi dalam pengolahan data mustahik, membantu kepala koordinator dalam pengambilan keputusan dengan cara yang lebih cepat, keakuratan hasil yang baik dan dapat mengurangi penilaian secara subjektif dalam penentuan penerima dana zakat

\section{REFERENCES}

[1] Kusrini. 2007. Konsep dan Aplikasi Sistem Pendukung Keputusan. Andi. Yogyakarta.

[2] Pratiwi, Heny. 2016. Buku Ajar Sistem Pendukung Keputusan. STMIK Widya Cipta Dharma. CV Budi Utama.Yogyakarta.

[3] Fuadi. 2016. Zakat Dalam Sistem Hukum Pemerintahan Aceh. Deepublish, Yogyakarta.

[4] El-Bantanie, M. Syafe'ie. 2009. Zakat Infak dan Sedeka. Salamadani. Bandung.

[5] Pratiwi, Heny. 2016. Buku Ajar Sistem Pendukung Keputusan. STMIK Widya Cipta Dharma. CV Budi Utama.Yogyakarta.

[6] Mardalis., 2014, Metode Penelitian Suatu Pendekatan Propos. Bumi Aksara. Jakarta. 
[7] Murhada., Giap, C, Y. 2011. Pengantar Tekhnologi Informasi. Mitra Wacana Media. Jakarta.

[8] Usman, H., Akbar, S. P,. 2014. Metodelogi Penelitian Sosial. Bumi Aksara. Jakarta.

[9] Kuncoro, Mudrajat. 2009. Metode Riset untuk Bisnis \& Ekonomi. Edisi 3. Erlangga. Jakarta.
[10] Pressman, S. R. 2014. Software Engginering : A. Practicioner's Approach, Seventh Edition (Rekayasa Perangkat Lunak : Buku Satu, Pendekatan Praktisi (Edisi 7), diterjemahkan oleh Nugroho, A., Nikijuluw, L, J, G., Rochadiani, T, H. Andi. Yoyakarta. 